\title{
Comment on Selected Aspects of Proposals in Public Consultation Document on Addressing the Challenges of the Digitalization of the Economy
}

\section{Citation}

Stephen E. Shay, Comment on Selected Aspects of Proposals in Public Consultation Document on Addressing the Challenges of the Digitalization of the Economy (Mar. 6, 2019).

\section{Permanent link}

http://nrs.harvard.edu/urn-3:HUL.InstRepos:38586353

\section{Terms of Use}

This article was downloaded from Harvard University's DASH repository, and is made available under the terms and conditions applicable to Other Posted Material, as set forth at http:// nrs.harvard.edu/urn-3:HUL.InstRepos:dash.current.terms-of-use\#LAA

\section{Share Your Story}

The Harvard community has made this article openly available.

Please share how this access benefits you. Submit a story.

\section{Accessibility}


March 6, 2019

Tax Policy and Statistics Division

Centre for Tax Policy and Administration

Organization for Economic Co-operation and Development

2, rue André Pascal

75775 Paris Cedex 16

France

Subject: $\quad$ Comment on Selected Aspects of Proposals in Public Consultation Document on Addressing the Challenges of the Digitalization of the Economy

Dear Inclusive Forum Delegates:

This letter responds to a request for comments on the 13 February 2019 Public Consultation Document on "Addressing the Challenges of the Digitalization of the Economy." 1 This letter reflects the personal views of the author and has not been prepared on behalf of or at the request of any business or other organization. I attach a short summary of my professional background as an annex to this letter.

The purpose of this comment is to support a re-alignment of the division of corporate income between source and residence countries. The proposal in the Consultation Document that has the greatest potential to achieve a meaningful realignment is the "significant economic presence" proposal in the first pillar, provided that it is not linked exclusively to digital activity (which in concept it is not or need not be). The trigger for focus on this issue by the Inclusive Forum is the failure of anachronistic proxies for income division, based significantly on where physical activity is performed and assets located, to prescribe what income source countries can and cannot tax. The failure of these historic rules is not solely attributable to the pressures of digitalization, but also extends to weaknesses and inadequate realism in transfer pricing rules.

Consideration of a broader realignment of taxing rights also is appropriate to address the structural imbalance that results from (i) a global shift away from residual residence taxation, (ii) subsidy of international investment by allowing residence country deductions and losses attributable to income exempted from residence taxation, and (iii) the inability or failure of source countries to tax income that is shifted to intermediary countries. The result under the current regime is revenue loss and distorted investment incentives that favor international over domestic investment and international investors over domestic investors. The primary beneficiaries are multinational businesses and their shareholders.

\footnotetext{
${ }^{1}$ OECD, Public Consultation Document on Addressing the Challenges of the Digitalization of the Economy (Feb. 13, 2019) (hereafter “Consultation Document”).
} 


\section{Initial Observations}

\section{A. Move Beyond BEPS}

I applaud the willingness of the Inclusive Forum to consider fundamental changes to the structure of the international tax system that go beyond what was contemplated in the Base Erosion and Profit Shifting (BEPS) Project. It is extremely important that members of the Inclusive Forum collectively address longstanding issues in the international tax system that have restricted the claim of source countries to tax economic activity that derives value from the source country and accordingly results in over allocation of income to residence countries. (In recent decades, the "residence" country often is a low-tax intermediary country.) These issues are exacerbated by but are not attributable exclusively to digitalization of the economy.

The lack of congruence of the historic paradigms on which international tax rules were based and current business practices has been apparent since late in the last century. The disclosures in the current decade, however, of the extent of cross-border multinational tax avoidance have generated a degree of political will to make changes.

There is no doubt that, if fully implemented, BEPS action items would constrain to some degree income shifting to low- or no tax intermediary countries. There is substantial optionality for countries to adopt many BEPS items and how to implement others (including mandatory elements such as the substantial nexus standard). Unsurprisingly, national implementation is strategic depending on each country's perception of its self-interest. While the BEPS project was positive overall and addressed some important issues, the longer term impact of BEPS remains an open question.

It is a sound decision to extend the discussion of options beyond BEPS. This consultation provides an opportunity to point the project in a direction that over time will allow tax systems to raise revenue fairly and on a sustainable basis.

There is little doubt that adoption of a broad global minimum tax, without the design flaws of the U.S. GILTI regime, could be a dramatic post-BEPS improvement in the international tax regime. However desirable, there is a low likelihood that support can be found for a sufficient scope of increased residence taxation of low-taxed income to effectively combat income shifting. Moreover, the most direct beneficiaries of such proposals are the wealthy capital exporting countries. Accordingly, this second pillar proposal warrants work, but at a lower level of priority unless or until there is political will to adopt a robust measure.

The anti-base erosion payments rule also is a worthy project, but the related party condition and treaty rule limits the scope to mere anti-avoidance and is not a realignment of taxing rights between source and residence countries. Accordingly, it is another extension of the BEPS project and would not address the structural problems that exist in the system. It might be useful in the eyes of some as an analogue to and improvement upon the U.S. BEAT provision, but that also should be a project given a lower level of priority than the subject of this consultation. 
Recent developments have demonstrated the weaknesses, both technical and political, of pursuing a partial digital-only solution to more systemic issues in the allocation of the right to tax income among jurisdictions. Commentators worthy of attention have pointed out how digital only responses will result in distortions and unfairness. I share that perspective, but do not develop it in detail in this comment. The user participation proposal is deeply flawed as a result of its limitation. The Amazon site that I sign on to operates simultaneously both as an online marketplace for unrelated sellers and buyers as well as an Amazon selling channel. It does not make sense to try to break those apart for purposes of taxation by a source country.

It is time to reset the division of income between residence and source countries. To achieve that without disruption, it is important to reach agreement: (i) that a source country has a legitimate taxing claim on a taxpayer that engages in significant economic activity in its economy whether or not the taxpayer has a physical presence in the country, and (ii) on methodologies for attributing income to the source country in those circumstances. This is a challenging task and not one suited to a fast process based on the state of discussion reflected in the Consultation Document and preceding reports.

The process to find a sustainable long-term solution, should be deliberative and iterative as models are developed, their effects assessed with the best data available and further pressure tested in relation to varied economic assumptions and various business models. This comment is intended to contribute to such a process, but it also is a preliminary contribution.

The proposed time line for this project is too truncated to allow the amount of analysis that is required to achieve broader change. It plays into the hands of those interests with the resources to operate on short deadlines and that prefer the status quo and minimal change. I encourage the Inclusive Forum to obtain G20 agreement to a time line that would permit responsible development of a proposal to realign taxing rights.

\section{Expanded Source Taxation of Remote Sellers and Their Owners}

\section{A. A Sustainable Long-Term Solution Should Be Comprehensive}

There is emerging agreement that source countries have a legitimate claim to a larger share of income in relation to a residence country from which the investment ultimately is owned in circumstances where the remote seller is "heavily involved in the economic life of a jurisdiction without a significant physical presence.”2 To date, however, a consensus has not been reached on a methodology to attribute income of a taxpayer to a virtual permanent establishment or its equivalent, a place of business or agency permanent establishment resulting from activity of an affiliate already compensated on an arm's length basis. ${ }^{3}$ The income attribution issue is the most

\footnotetext{
${ }^{2}$ Consultation Document, $₫ 50$.

${ }^{3}$ Indeed, the absence of a clear methodology is one reason some countries have declined to agree to an expanded permanent establishment standard that would bring within the source country taxing net the income of a remote seller attributable to the non-physical economic activity of that taxpayer.
} 
significant hurdle to a realignment of taxing rights and the one to which this comment is primarily addressed.

An issue that precedes how much income should be attributed to a non-physical use of a source country's economy is what activity (and at what level of activity) should a non-physical business involvement in a country's economy be sufficient for that source country to assert taxing jurisdiction? This issue is distinct from but overlaps with the administrative issue of to which taxpayers should “remote PE” rules be applied?

In answering this question, I encourage the Inclusive Forum to not limit its focus to a particular form or aspect of business activity, including one linked exclusively to "digital technology and other automated means." ${ }^{4}$ Digital is just a form of communication and if physical mail (or smoke signals) can achieve a similar result at more than di minimis scale, there is not a sound basis to distinguish between the methods. Notwithstanding the appeal of the distinctions of (i) scale without mass, (ii) heavy reliance on intangible assets, and (iii) data and user participation, it would be unwise to create an incentive to use paper catalogues and (wireless) telephones instead of internet transmission.

Similarly, the scope of the proposal should not be restricted to marketing intangibles. While the marketing intangibles proposal is a significant step in the right direction, particularly in its recognition that it often is appropriate to allocate income to a source country where the only physical presence is a limited risk distributor (LRD), it seeks to describe a distinction that is not well defined and not capable of meaningful definition. Unless broadened, this approach inevitably would create a distortion between B2C and B2B sales that can be manipulated.

There is not a clear line between a marketing intangible and a trade intangible for purposes of these issues. Take the Apple iPhone as example. Is the investment in the design features of the phone a marketing intangible or a trade intangible directed at product performance? I would suggest that Tim Cook and Jony Ive might argue cogently that much of the design was to enhance customer delight in owning the product. Many designs are patented, but many are copyrighted and trademarked as well. The trade versus marketing intangible distinction is not meaningful nor sustainable across a broad range of fact patterns.

Another item that needs attention in any comprehensive approach to re-aligning source taxation is how to address offshore indirect transfers such as those considered in the revised discussion draft by the Platform for Collaboration on Tax. ${ }^{5}$ Analogous concerns to those discussed in connection with offshore indirect asset transfers arise in connection with remote owners who sell interests in entities that engage in remote activity having a significant economic affect in a jurisdiction. Because work is being conducted with respect such offshore asset transfers, this comment does not take up that issue but it is a critical part of any re-alignment of taxing rights between residence and source countries. As discussed below, the idea of location specific rents

\footnotetext{
${ }^{4}$ Consultation Document, $\mathbf{9 5 1 .}$

${ }^{5}$ Platform for Collaboration on Tax, The Taxation of Offshore Indirect Transfers - A Toolkit (Rev. draft 2018)
} 
referred to in that report should be utilized as well in considering what remote activity derives value from the source country's economy.

\section{B. Employ Income Tax Principles and Concepts}

Before resorting to a new tax instrument, it is appropriate and important to determine if it is possible to achieve a re-alignment of taxing jurisdiction using modifications of existing income tax principles and concepts. It is premature to abandon the corporate income tax and undertake the far more uncertain and disruptive shift to a new tax instrument, such as a destination based cash flow tax, or to rely exclusively on a destination based VAT. In addition to the practical fact that in 2017 a form of cash flow tax was politically rejected in the United States, cash flow tax proposals have not been worked out sufficiently to be put in service and have not been pressure tested adequately to be put forward as a global solution. Cash flow tax proposals to date almost universally have promised more than they can deliver under any plausible form in which they would be enacted in a democratic state. The VAT has an important place in revenue generation, but it is not a substitute for taxing the full return to capital.

Integrating taxation of a remote seller into existing income taxation rules is most likely to minimize the difference in treatment of a remote seller and an in-country seller. Specifically, there should be allowance of relevant deductions in the source country and, if the residence country exempts the income, disallowance of the deductions in the residence country. In order to avoid discouraging remote activity that is beneficial to the source country it also is necessary to agree on rules that mitigate or avoid double taxation (as well as double non-taxation).

\section{Remote Sellers - Source Taxation of Which Entity?}

As a conceptual starting point, income deriving its value from the economy of the source country should be within the agreed scope of source country taxation. Any member of a group that earns such income could be subject to source country tax. For purposes of this discussion, it will be assumed that the aggregate income earned by each such entity is an arm's length amount. The objective is to determine what portion of the income of each member of the group derives its value from the source country.

The entity that makes sales directly into the source country most clearly earns income deriving value from the source country. It quickly becomes apparent that a group supplier to that entity also may be considered to earn income "deriving value from" the economy of the source country. ${ }^{6}$ This complexity appears to be why the U.K.'s HM Treasury sought to look at the “principal” in a group that earned residual profit. ${ }^{7}$ The HM Treasury approach, however, limits

\footnotetext{
${ }^{6}$ The same may be true of an unrelated supplier to the group selling to the source country, but this is likely to be a narrower group of companies if the sales to the group are not directed at sales to the source country. Nonetheless, the case where sales to the group making direct sales to the source country also must be addressed or there would be too great a disparity in treatment of related and unrelated parties performing the same activity. This preliminary discussion is limited to the treatment of a group selling to a buyer (whether an intermediate or final consumer) for use, consumption or disposition in the source country.

${ }^{7}$ HM Treasury, Corporate tax and the digital economy: position paper update, 13.30 (Mar. 2018).
} 
the source country claim to a share of the residual profit (and not all groups are so conveniently organized as to have a single “principal”).

As a conceptual matter, the residual profit approach denies the source country a claim to tax the "normal return" to investment, whether in human capital, intangible value or tangible investment, that is directed at earning income that derives value from the source country. An issue to be resolved in response to the HM Treasury proposal is in what circumstances the normal return should be reserved to the residence country and in what circumstances should it be subject to source country taxation. In thinking about this question, it is important to recognize the limitations of the construct of a "normal" return, including the implication of that construct that would have the residence country also bearing all losses from failed investment. ${ }^{8}$

Clearly there is an administrative advantage if a single group company has responsibility for implementing the payment of source country tax, but that is a design issue that should be resolved after it is determined what income should be taxed. There may be a solution to the administrative concerns that is analogous to having a single company be responsible for the tax liability of a group (or having a single country provide a passport for conducting business in an entire regional market).

\section{Remote Sellers - What Income Should Be Subject to Source Taxation?}

The fundamental question is what income should be considered to "derive value from" the source country? I have previously argued (with co-authors Fleming and Peroni) that income does not have an inherent geographic source, referring to the insight of Hugh Ault and David Bradford, and that many of our rules for assigning income to a jurisdiction are rules of convenience that serve as a proxy for a geographic connection. ${ }^{9}$ Almost all such rules first require classification of income and second incorporate some element of physical presence as part of the proxy for identifying the source of the income category in question. For example, personal services are usually assigned to where the services are performed.

Even the narrowest of the Consultation Document pillar 1 proposals recognize that something like advertising services may be delivered from one country but derive value in the source country without a taxable presence there. ${ }^{10}$ The objective of this section is to identify what other income should be considered to derive value from the economy of the source country. As discussed below, once the standard is identified it is possible to use existing rules and tools to develop metrics for attributing income to the source country in a way that accords with the contribution of the market country to value.

\footnotetext{
${ }^{8}$ Alternatively, the HM Treasury proposal would permit the source country to tax a company with which users (of the digital business) have some connection. This leaves to be resolved the problem of the supplier to the entity with which the "users" have a connection discussed above. If this is not addressed simple entity planning would allow income to be shielded from source country taxation.

${ }^{9}$ Stephen E. Shay, J. Clifton Fleming, Jr. \& Robert J. Peroni, The David R. Tillinghast Lecture: "What's Source Got to Do With It?” Source Rules and U.S. International Taxation, 56 Tax Law Rev. 81 (2003).

${ }^{10}$ This would overturn the result of the U.S. case long relied on to justify residence taxation of cross border advertising and similar services that can be performed remotely. Commissioner v. Piedras Negras Broadcasting Co., 127 F.2d 260 (5 ${ }^{\text {th }}$ Cir. 1942).
} 
One way to identify income of a business that would be subject to source taxation would be based on the investment in business assets, broadly understood to include real, tangible, intangible and human, that are directed at consumption in the source country, whether by an intermediate or final consumer (i.e., in B2B or B2C sales). These assets would include but not be limited to a marketing intangible.

As an example of source country value for a non-marketing intangible, assume that a Canadian exploration company develops a process for removing an ore impurity that only is found in iron ore deposits in West Africa. Surely, a portion of the return from that process is attributable to the sales made in the West African countries where such deposits are located, yet such a process normally would not be considered a "marketing intangible." In this case the asset earns what may be considered location specific returns from a source country that equally justify source country taxation as the return to a marketing intangible. The Platform's report on offshore indirect transfers points to analogous assets.

If there is going to be a realignment of taxing rights, there needs to be developed a set of standards for determining when an expenditure is sufficiently directed at the purchaser/consumer of the good or service that the return on the investment to which the sale contributes (whether the return is positive or negative) is assigned to the jurisdiction(s) of the consumer(s). The question might be thought of as what assets used in the taxpayer's business would a business selling to consumers in that country and acting at arm's length want to possess or acquire rights to? In a world of realigned taxing rights, the return on those assets should be allowed to be taxed by the source country without regard to physical presence.

Let me start with a simplified example. Assume that Company A (i) develops the design and process for manufacturing a widget, (ii) manufactures the widget, and (iii) sells the widget. Let us assume that sales are in Company A's residence country, Country X, and in Country Y. Assume that Company A has an affiliate, Company B, in Country $\mathrm{Y}$ that performs as a sales representative for the widgets in Country $\mathrm{Y}$ in a manner that would not cause Company A to have a permanent establishment in Country Y. Sales to Country Y customers are made under a trademark (W) developed and owned by Company A and registered in Country $\mathrm{X}$ and Country Y.

Before turning to how to determine what portion of Company A's income should be taxed in Country Y, let me first assume alternatively that Company A sells widgets in Country Y through online sales instead of using its affiliate as an in-country non-PE sales representative. It is likely that Company A's selling costs will decrease in some amount, but the premise of this comment is that source Country Y should have the same right to tax Company A under either set of facts. In both cases, Company $\mathrm{A}$ is selling in Country $\mathrm{Y}$ and earning income deriving value from the Country Y economy.

I now turn to the more difficult problem of how to attribute income of Company A to Country Y in the absence of a physical presence. In numerous transfer pricing controversies, consulting economists have emphasized the conservatism or reliability of using a return on assets as a metric to divide income of a firm so I use that approach in this example. 
A difficulty posed in the modern knowledge-based economy is that traditional tax accounting often does not fully capitalize expenditures for human capital assets or for self-developed intangibles, so it is difficult to identify and measure the investment in intangible assets used in a business. Nonetheless, identifying the investment in such assets based on costs contributing to their value may be undertaken as an adjustment to a traditional balance sheet. This concept and approach is not novel. For example, the U.S. passive foreign investment company (PFIC) rules include comparable approaches to build an R\&D asset in applying an asset test. ${ }^{11}$ I have participated in transfer pricing controversies where similar adjustments to apply a return on assets method have been made either as part of a primary method or as a check on a primary method presented to a tax authority.

In the example described above, assume that Company A has three bundles of assets, one an intangible bundle $(\mathrm{S})$ consisting of patents, copyrights, trade secrets and know-how covering the widget design and manufacturing process, another bundle of tangible assets $(\mathrm{T})$ comprising the manufacturing plant and equipment used to manufacture widgets, and a third bundle (U) comprising the trademark and other marketing intangibles directed at the consumers of the widget. Also assume that Company A identifies its investment in self-developed intangibles for this purpose by capitalizing expenditures that contributed to those intangible assets. When this is done, assume that the three bundles have an investment of 30 for S, 30 for T and 40 for $\mathrm{U}$. Finally, assume that sales are made $60 \%$ in Country $\mathrm{X}$ and $40 \%$ in Country $\mathrm{Y}$. Using a return on assets approach, Country Y would have a right to tax 16\% of Company A's pre-tax profits (40\% of Company A sales times the $40 \%$ of Company A consumer-directed investment).

If, alternatively, one half of bundle S (say, some of the design or process portion) is directed at consumers, then 15 of the 30 investment in S should be associated with consumers so that 55\% of total investment is so directed. In such case, Country Y would have a right to tax $22 \%$ of Company A’s profits.

What if Country Y declines to assert its jurisdiction to tax income earned without a physical presence? Then that income could be allocated to the remaining countries in which sales are made.

The objective of this section has been to do no more than sketch a framework for how income could be attributed to a source country in the absence of a physical presence or alternatively a permanent establishment using existing concepts and tools. The approach described would be consistent with the arm's length standard. The methodology described certainly is not the only one, but it follows reasonable and established methods. Assets are identified that benefit from the economy of the source country under a standard of whether an unrelated person would use them to carry on business in the market. Once those assets are identified, they are allocated a return actually earned by the company in that business. This is a reasonable basis on which to test whether the amount attributed to the source country would be consistent with returns that over the life of the business that would justify investment in that market.

${ }^{11}$ I.R.C. $\$ 1298(e)$. 
There are many potential complexities that need development and testing and there are alternatives to be explored beyond what has been possible for me to undertake since February 13. I consider it important, however, that the Inclusive Forum broaden the discussion to consider what a full realignment of tax jurisdiction based on a significant market involvement might look like. If nothing more, it is important to acknowledge that a path exists within the principles of the corporate income tax to allow a greater share of income to be taxed by source countries while also addressing the realities of modern business structures and capabilities.

The next sections take up additional issues. What thresholds should apply before a taxpayer would be subject to source taxation in a jurisdiction, what protections should there be to avoid double taxation of the same income, and what information should taxpayers be required to supply to develop the profit split described above.

\section{E. Thresholds for Taxation of Remote Sellers and Avoiding Double Taxation}

There should be a threshold of activity representing involvement in a source country economy before there can be a taxable presence. A variety of alternatives have been proposed in different contexts. I do not make or comment on specific proposals here, but agree that a threshold should include a metric for sufficient activity in terms of regularity or size to justify source taxation. In addition, there should be a taxpayer-based de minimis threshold below which source tax jurisdiction is not asserted in relation to a taxpayer.

If (and only if) a source tax is imposed, there should be protection from double taxation. In theory, relief could be by the source country to take account of residence taxation or by the residence country to account for source country taxation. I favor the latter. Care need be taken under either approach to not create an authorized case of double non-taxation.

\section{F. Information Necessary to Implement Proposal}

The analysis described above should be on a line of business basis. Some may ask whether information would be available to undertake that analysis. While not minimizing the issue, this also has been addressed and has precedent in U.S. information reporting required for non-U.S. multinational companies with a U.S. affiliate. A Treasury regulation, which is in force, requires U.S. affiliates of foreign-controlled groups to maintain the records (including from non-U.S. affiliates) necessary to create a "see-through" profit and loss statement by product line if certain thresholds are satisfied. ${ }^{12}$ In my view this information could be required in country-by-country reporting.

\section{Conclusion}

The purpose of this comment is to encourage the Inclusive Forum to work on developing a broad principles and fact-based proposal to expand source country taxing rights to solve longstanding structural problems that are not limited to digital businesses or digital-based activity.

\footnotetext{
${ }^{12}$ I.R.S. Reg. §1.6038A-3.
} 
Thank you for your consideration of these comments. I would be pleased to answer any questions you might have.

Sincerely,

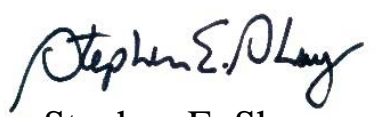

Stephen E. Shay

19A Berkeley Street

Cambridge, MA 02138

sshay@law.harvard.edu

STEPHEN E. SHAY

Cambridge, MA 02138

Office Telephone: (617) 384-5311

E-mail: sshay@law.harvard.edu

Stephen E. Shay joined the Harvard Law School faculty as a Professor of Practice in 2011 and since 2015 has been a Senior Lecturer on Law. Previously Mr. Shay was Deputy Assistant Secretary for International Tax Affairs in the United States Department of the Treasury from 2009 - 2011. Prior to joining the Treasury Department in 2009, Mr. Shay was a tax partner for 22 years with Ropes \& Gray, LLP. Mr. Shay served in the Office of International Tax Counsel at the Department of the Treasury, including as International Tax Counsel, from 1982 to 1987. Mr. Shay is a Past President of the American Tax Policy Institute Board of Trustees and serves on the Executive Committee of the New York State Bar Association Tax Section. Mr. Shay is a 1972 graduate of Wesleyan University and he earned his J.D. and his M.B.A. from Columbia University in 1976. 